\title{
PRACTICAL RESEARCH RESULTS OF A SUCCESSFUL COMPANY'S APPEARANCE AT THE FAIR
}

\author{
Nedeljko Prdić1, Boris Kuzman ${ }^{2}$, Miljana Barjaktarovic ${ }^{3}$
}

\begin{abstract}
Summary
Trade fairs represent a hot subject in the contemporary theory, as well as in the contemporary practice of modern successful international and local enterprises, organisers and owners of exhibition space. The domestic literature provides certain sources and papers which discuss the topic in theory, but there is an evident lack of strategic approach towards trade fairs as the instrument of sales improvement, as well as the obvious lack of practical approach of enterprises at trade fairs, and the lack of real measurement of the results obtained.

This paper proves that the representation on a trade fair had positive effect on the sales results, as well as on the creation of interest and the increase of awareness of the existence of a company and its products. The analysis proves that under certain conditions the gain rate on the investment is calculable and quantifiable, in the case of trade fair representation.
\end{abstract}

Key words: trade fairs, wine, costs, effects of appearance.

JEL: $Q 13$

\section{The research topic and research objective}

The research topic is appearance of an enterprise at trade fair and its effects on the results of the company's sales. The professional communication of an enterprise at trade fair and successfully concluded sales cane be defined as a skill of representing products and/ or services in a way so attractive and efficient that the buyer feels immediate and direct pleasure caused by product or service, and that the result of the whole process is the decision of buying (Prdić, 2009).

This research is aimed to conclude what is the rate of profit on the investment done by an enterprise which appears at a trade fair and introduces two of the new products. The basic

1 Nedeljko Prdić, Ph.D., JKP Tržnica, Žike Popovića Street no. 4, 21000 Novi Sad, Serbia, Phone: +381 63500 818, E- mail: ekonomistdoo@,sbb.rs

2 Boris Kuzman, Ph.D., Research Associate, Faculty of Agriculture, Trg Dositeja Obradovića no. 8, 21000 Novi Sad, Serbia, Phone: +381 63590 129, E-mail: kuzmanboris@yahoo.com

3 Miljana Barjaktarović, Ph.D., Professor, Alfa University, Palmira Toljatija Street no. 3, 11000 Belgrade, Serbia, Phone: +381 6944106 20, E-mail: miljana.barjaktarovic@alfa.edu.rs

EP 2014 (61) 4 (903-914) 
objective of this paper is to establish what is the rate of profit on the investment which is made by a company appearing at a trade fair, in terms of positive effects on the results of the company's sales.

The objective of the research is establishing solid ground for future researches, both theoretical and empirical, which will show in practice all their validity based by certain statistical and other methods that can be utilised in practice and possibly point out to certain causal relationships.

\section{Methods of research}

This paper uses, amongst other methods, the comparative method of marketing research, which represents a combination of historical method and examination method. Special methods of cognition and acquiring knowledge are both analysis and synthesis, methods of statistical data processing, and the data are represented visually by tables and diagrams. The traditional application of a historical method viewed from the angle of a company that exhibits at a trade fair, is marked and established by inertia which is shown in following and comparing costs from the last year's appearance, augmented by changes from this year, or, rhetorically speaking, represented by fear that the competitor's company will appear at trade fair and by this appearance it will endanger the market position of our company if our company fails to appear at the trade fair in question. It causes our company to be forced to appear too. Modern approach assumes using trade fair as an instrument for sales improvement in order to achieve competitive advantage, treating costs of the trade fair appearance as an investment. As in the other instruments of competitive advantage, marketing communication and sales improvement, it is needed to establish the rate of profit on the investment, and the rate mentioned is produced by a company's appearance at trade fair. A special method of calculation for the quality/price ratio is metha-regression analysis, which uses scale from 1 to 100 to assess the quality (Oczkowski, Doucouliagos, 2014).

As in the other instruments of competitive advantage, marketing communication and sales improvement, it is not clearly computable in a precise manner how big the effects of such trade fair appearance are. The possible influences that could be treated as "noise" are the influences of other instruments of marketing communication. Based upon communicational cognition and knowledge gathered from practice, i.e. from the research conducted at Novi Sad Agriculture Fair, it is possible to measure the profit rate caused by trade fair appearance with certain "assumptions".

\section{The results of the research}

\section{The Presumptions of the Research}

The need for practical measurement of the efficiency of trade fair appearance has appeared as an imminent occurrence in all companies present on the market, mostly because of the limited resources for achieving business goals. The assessment and control of the achieved targets of the company's trade fair appearance is based upon comparison of wished, targeted objectives with the achieved results. It is done by assessing the profit 
rate on the investment during launching a new product on the market. It is a well-known fact that Germany is the leading country in trade fair industry in the world. From all the leading trade fairs in the individual sector, two thirds are being held in this country (www. auma.de).

If we know that the trade fairs are one of the most important instruments of sales improvement, as well as one of the leading and most effective instruments in launching new products on the market in developed countries with market economy, the objective of this research is to show practical importance of a trade fair appearance for every company in the domestic circumstances. This is the case also when we analyse the wine products. This particular analysis is being centred around the two products of the Wine Manufacturer, ,Vršački vinogradi“, Product One being Red wine Frankovka, 0.187 litters, and Product Two being White wine Muskat, 0.187 liters. This research is conducted with the approval of the manager of the trade fair appearance of this company.

We assume the following situation:

C1. "Pure market situation": The situation which is characterised by the lack of communicational activities or by their low level. The same applies to the activities of direct sales. Elimination of such instruments of communication releases from the obligation of researching potential interconnections between different instruments of marketing communications, and enables the establishing of effects caused by the trade fair appearance to the volume of sales achieved, as well as the other communication effects. This situation can be considered realistic having in mind that the new products are being mostly launched and demonstrated mainly at trade fairs.

C2. Introducing of a new product at a trade fair: introduction of a new product at a trade fair relinquishes from the need to measure influence made by other elements of marketing communication. The advantages of products exhibited are quality, proven by the quality of geographic origins, the uniqueness of wines like Frankovka and Muskat, the own plantations of the vineyards, and one of the most important comparative advantages of the product is design which follows trends of the time. The effects of the sales and other communication results can be attributed to the company's trade fair appearance. Three months after the trade fair is the period taken for measuring effects, measured from the date of introduction of a new product on the market. The example of the Austrian wine market we see that the wine of better quality is produced by bigger companies, in comparison with smaller companies joint into societies (Pennerstorfer, Weiss, 2012).

C3. Conquering new markets and market segments. If we know that this objective of trade fair appearance is one of the most important ones, and that stands in direct proportion with launching of a new product, such market situation enables measuring of the effects and their connection with the trade fair appearance only.

C4. Market position of the company. The company that made the trade fair appearance, which also took all the steps for realization of the project of the trade fair appearance, possesses concrete data on volume of sales of a new product introduced, as well as the 
data on products which were not shown nor exhibited at the trade fair, and also other communication effects of the trade fair appearance, analysed in the measured time frame needed for evaluation.

The results of the research are shown regarding measurement of economical and communicational effects. The rational measurement of results of a trade fair appearance is possible only with the assumption that the company took all the necessary steps embedded in the model of successful management of activities of a successful trade fair appearance (Prdić, 2012a).

The economic effects of such trade fair appearance, under aforementioned presumptions, would be:

Presumption $1(\mathrm{P} 1)$

o The volume of realized sales per buyer for the products exhibited at the trade fair would be bigger for the buyers that visited the stand, than the volume of realized sales per buyer for those buyers who did not visit the stand of the company.

Presumption 2 (P2)

o The increased business results (profit) resulted from the bigger volume of sales, having in mind all mentioned under 1), in the case of exhibited on the stand, will cause positive profit rate for the trade fair appearance investment.

Trade fairs are communicational and sales orientated market institutions and the exhibiting company expects positive profit rate on the invested assets, in form of increased direct sales at trade fair or in the certain time frame after the trade fair, which is in accord with our first presumption, i.e. that the increased sales must be bigger than total costs of trade fair appearance, so that the investment can be economically payable and profitable, which is then again in accord with the presumption of the appearance.

The communication effects would therefore be the following:

Presumption 3 (P3)

o Potential buyers who visited the company stand will have communicational knowledge about the company's image, as well as other direct knowledge about the product and its features, that the ones who did not visit the stand.

Presumption 4 (P4)

o Having communicational knowledge on trade fair exhibit space, visitors who visited the company stand would be more interested in a product that those who did not visit the company stand.

Most of the relevant sources from the area of marketing and marketing communications are focused on so-called hierarchy of effects of the advertising messages, where the efficient instruments of marketing communication have to have a positive effect on the initial levels in the hierarchy. This perception is in accord with aforementioned communicational 
presumptions. Aforementioned presumptions are a reflexion of a conventional thinking of companies appearing at trade fairs.

In order to do the research successfully, as well as to achieve practical effects which can contribute to the positive effects in operating of domestic companies, and having in mind aforementioned presumptions and "accepted features" of economical and communicational effects that this research has to have, in C4 we will put the data of "Vršački vinogradi", since we obtained cooperativeness of the company's management. We can note that this research is just a beginning in terms of practical testing based upon precisely guided data. Therefore they have to be double-checked if the number of companies grows. This does not diminish the value and validity of this research since obtained data from various companies can always be practically utilised, all based upon this research.

Our example will be a company which produces wine products and which exhibits in a number of trade fairs or wine festivals. The biggest trade fair in the agrarian sector is the International Agricultural Fair in Novi Sad held annually, which is attended by all the relevant wine manufacturers from Serbia and wider region. Apart from the geographical origin of the wine, the factor which influences the pricing of the wine is the assessment of quality on fairs (Schamel, 2003). The aforementioned company introduced two new products at the International Agricultural Fair, Product One being Red wine Frankovka, 0.187 litters, and Product Two being White wine Muskat, 0.187 litters. Therefore the C2 Presumption. This fair is always visited and the visitors are very numerous. The number of competitors is high so it could be considered relevant for the research.

For the successful research of the indirect effect of trade fairs we need to compare the number of existing and future buyers who visited the company stand (E-experimental group which consists of company stand visitors) and those who did not visit the stand or did not visit the fair at all (G-control group). In order to fulfil the condition from the Presumption $\mathrm{C} 3$, we need to compare the groups of relevant dimensions.

In our case, the company contacted its existing and potential buyers one month prior to the trade fair using direct mail or e-mail about their fair appearance. The company stated that there were new products on the company stand, but did not specify which those were. The communicational activities on the company stand have shown that the company stand was visited by 1,500 visitors (by a questionnaire) who had not been previously invited to the stand. These 1,500 visitors represent the number of visitors during the trade fair and they represent the E-group. The other buyers and potential buyers who did not visit the stand represent the G-group.

The intentions of buyers to buy a certain product which was exhibited at the trade fair can be brought in accord with previous buying intentions, by the research made by a questionnaire after the trade fair. This research is important because of the fact that the visitors who were at the fair had had buying intentions for the exhibited products, much more than the potential buyer who did not visit the fair. Therefore it is possible to explain the increased sales of the company's products by the visitors of the trade fair by their increased wish to buy products. It would mean the adjustment of the achieved economic effects in this research. By this research 
we need to find out the differences between the intentions of the visitors who visited the trade fair and the company stand and those who did not visit the trade fair, as well as those who visited the trade fair, but not the particular stand.

The visitors of the company stand can be existing or potential buyers and consumers. By communicating at the trade fair we can influence existing buyers because they possess a certain loyalty to the company's products, more than the potential buyers. The research of attitudes and perceptions of potential buyers is necessary to be performed prior to the trade fair, so that we can influence their buying intentions when we talk about products or services of the company, and especially the new products exhibited at the trade fair for the first time. The research has to reveal the significance of the volume of the buyers' mass, which is reflected in volume of bought products or services and which is utilised as a basic variable for calculating the significance of the buyer for the company's business. We need to emphasise that the data on the sample volume do not make any difference between the visitors who visited the fair and not visited the stand, and those who did not visit the trade fair at all.

For the successful research of the company's significance and the precise measurement of the results we can divide all buyers into small, big and potential buyers as shown in the Table 1 .

Table 1. The characteristics of the trade fair visitors

\begin{tabular}{|c|c|c|c|}
\hline $\begin{array}{c}\text { Buyers' } \\
\text { characteristics }\end{array}$ & $\begin{array}{l}\text { Who visited the } \\
\text { company stand }\end{array}$ & $\begin{array}{c}\text { Who have not visited the company stand and } \\
\text { possibly have not visited the fair at all }\end{array}$ & Total \\
\hline Small & 246 & 1,889 & 2,135 \\
\hline Big & 203 & 1,052 & 1,255 \\
\hline Potential & 1,051 & 10,927 & 11,978 \\
\hline Total & 1,500 & 13,868 & 15,368 \\
\hline
\end{tabular}

Source: The results of the inquiry made by a questionnaire on the stand, during the Agricultural Fair in Novi Sad, the stand of Vršački vinogradi.

1. small buyers - purchases less than 1,500 EUR during last year,

2. big buyers - purchases bigger than 1,500 EUR during last year,

3. potential buyers - have not bought products or services of the company yet.

\section{The economic effects of a trade fair}

Today the efficiency appears to be one of the basic factors that mark the business success, market position and a mere survival of the modern company. The efficiency can be defined as the measure of achieving the objective.

The value analysis of a trade fair is a kind of a report which encompasses all the buyers and confidential individual report on clients, and it is used to compare the appearance of the company and the appearance of the competition. 
By analysing concrete example of this research, after finishing the trade fair, it is needed to question the visitors who visited the fair as well as the company stand. It is also needed question the visitors who did not visit the fair so that we can see what is the influence of the fair on the consciousness of the existence of the potential buyers of the product. This research has to determine the grade of consciousness for the two new products exhibited at the trade fair. In this case we need to apply the scale of ranking from 1 to 5 , where 1 represents the low interest (no buying intentions), whereas 5 represents very high level of interest (high buying intentions).

Table 2. Buying intentions prior to the trade fair

\begin{tabular}{|c|c|c|}
\hline \multirow{2}{*}{ Description } & \multicolumn{2}{|c|}{ Buying intentions prior to the trade fair (5-level scale) } \\
\cline { 2 - 3 } & Arithmetic average* & Standard error \\
\hline Small buyers & & \\
\hline -visited both fair and stand & $2.74(\mathrm{n}=90)$ & 0.23 \\
\hline -did not visit fair & $2.81(\mathrm{n}=86)$ & 0.18 \\
\hline Big buyers & & \\
\hline -visited both fair and stand & $3.41(\mathrm{n}=85)$ & 0.19 \\
\hline -did not visit fair & $3.12(\mathrm{n}=80)$ & 0.18 \\
\hline Potential buyers & & \\
\hline -visited both fair and stand & $2.48(\mathrm{n}=79)$ & 0.20 \\
\hline -did not visit fair & $2.33(\mathrm{n}=72)$ & 0.25 \\
\hline
\end{tabular}

Source: Authors' calculation based on the survey data.

Note: $* 1=$ no buying plans; $5=$ very defined plans; $\mathrm{n}-$ number of buyers

Monthly sales results for the two new product exhibited at the trade fair are shown in Tables 3 and 4. We monitored the sales in the period of 3 months after the end of the trade fair, as per buyers' category. This period is relatively independent from the other ,influences“ of other trade fairs, since other such trade fairs are not being held at the same time.

Table 3. Analysis of overall monthly sales after the end of the trade fair (new products only)

\begin{tabular}{|l|c|c|c|}
\hline \multirow{2}{*}{\multicolumn{1}{c|}{ Description }} & \multicolumn{3}{c|}{ Overall sales/buyers } \\
\cline { 2 - 4 } & $\mathbf{( 1 0}^{\mathbf{3}}$ RSD) \\
\cline { 2 - 4 } & May & June & July \\
\hline Small buyers, visited the stand $(\mathrm{n}=246)$ & 11.23 & 17.24 & 24.36 \\
\hline Small buyers, did not visit the stand* $(\mathrm{n}=1,889)$ & 2.84 & 5.72 & 9.21 \\
\hline Big buyers, visited the stand $(\mathrm{n}=203)$ & 18.24 & 70.61 & 125.68 \\
\hline Big buyers, did not visit the stand * $(\mathrm{n}=1,052)$ & 18.35 & 29.72 & 43.11 \\
\hline Potential buyers, visited the stand $(\mathrm{n}=1,051)$ & 3.58 & 4.70 & 5.14 \\
\hline Potential buyers, did not visit the stand* $(\mathrm{n}=10,927)$ & 0.39 & 0.84 & 1.25 \\
\hline
\end{tabular}

Source: Internal unpublished report on the sale of wine after the fair, Vršački Vinogradi a.d.

Note: * May have and may have not visited the trade fair; $\mathrm{n}$ - number of buyers.

We need to say that the period after the end of the trade fair is a bit unfavourable when we talk about the wine sales since the summertime comes, and the sales effects are generally smaller in this period. The conversations with managers have shown however 
that the real economic effects are expected in the beginning of September each year. The communicational effects at the fair itself are very significant because of the cognition of the product quality by tasting it and by comparing the products with others presented at the trade fair.

In the future period after the trade fair we need to write down the product sales in the next 3 months which is in accord with the management model of the company's trade fair appearance. From the point of view of this research, this time frame is relevant due to the fact that the other manifestations are not being held.

Analysing the results it is evident that the experimental group in every month after the trade fair achieved bigger sales volume if we divide the majority of individual sales by the number of buyers, than the control group. The aforementioned results show that the average sales per buyer who bought a product are bigger among those who visited the company stand during the trade fair. We need to mention that the two products were introduced to the market exactly during the trade fair, so we do not possess previous set of data for the sales volume. The bigger sales volume per buyer in the experimental group can therefore be attributed to the effects of the trade fair. The total positive effect after the visit to the company stand, as per the number of buyers as well as per cumulative sales per buyer for every category of buyers shows consistence with the economic effects as shown in the Table 3.

Analysing the economic effects on the products sales we can calculate the profit rate on the investment for the trade fair appearance. The overall economic effect for the two new products is calculated by multiplying the value of the achieved sales per category with the average gross profit rate. The short-term profit rates on the investment in percent represent the lower value of this fair in terms of short-term sales and in that respect it respects the P2. Observing the long-term period it is possible to determine the communicational and economic effects of the trade fairs. The cumulative sales calculated in the end of every month in the 3 observed months after the trade fair is in the function of time. The value of sales in the first months rises in the end of every month and after a while it decreases.

\section{The communicational effects of the trade fair}

In the communicational terms, trade fairs are an ideal instrument for communicating which serves adequately for establishing personal contact and assure that the direct utility of the product is tangible. The way in which the buyers sense things, their decision on purchase, however, show that the picture in the public and the image show the uniqueness of the product. The building of a corporate image is needed to represent the product positively.

Trade fairs are a good instrument to measure side by side different effects of personal communication, advertising, and trade fair in different phases of the purchase process.

The overall effect of the trade fairs as an instrument of sales development is shown in communicational effects of a company which appears at the trade fair. The communicational stimuli are utilised through different cognitive levels in the process of decision making. Correlation of chemical content of the wine and human perception of taste is still insufficiently 
studied (Saenz-Navajas et al., 2010). This research encompassed two phases of purchase, the consciousness of the buyer (considering the product) and the interest for the product. The measurement of the buyer's awareness after the fair is used when the goal of the fair presentation is used to improve the buyer's awareness of themselves, to launch the new product and to change the market perception (Prdić, 2012b).

Table 4. Cumulative analysis of consumers after the trade fair (new products only)

\begin{tabular}{|l|r|r|r|}
\hline \multicolumn{1}{|c|}{ Description } & \multicolumn{1}{|c|}{$\begin{array}{c}\text { Number of } \\
\text { actual buyers* }\end{array}$} & $\begin{array}{c}\text { Purchases as percent of } \\
\text { number of buyers }\end{array}$ & $\begin{array}{c}\text { Cumulative sales per } \\
\text { buyer(10 }\end{array}$ RSD) \\
\hline $\begin{array}{l}\text { Small buyers, visited the stand } \\
(\mathrm{n}=246)\end{array}$ & 18 & $7.3 \%$ & 333 \\
\hline $\begin{array}{l}\text { Small buyers, did not visit the } \\
\text { stand* }(\mathrm{n}=1,889)\end{array}$ & 65 & $3.4 \%$ & 268 \\
\hline $\begin{array}{l}\text { Big buyers, visited the stand (n } \\
=203)\end{array}$ & 47 & $23.2 \%$ & 343 \\
\hline $\begin{array}{l}\text { Big buyers, did not visit the } \\
\text { stand** ( }=1,052)\end{array}$ & 136 & $12.9 \%$ & 257 \\
\hline $\begin{array}{l}\text { Potential buyers, visited the } \\
\text { stand ( } \mathrm{n}=1,051)\end{array}$ & 21 & $2.0 \%$ & 180 \\
\hline $\begin{array}{l}\text { Potential buyers, did not visit } \\
\text { the stand** }(\mathrm{n}=10,927)\end{array}$ & 76 & $0.7 \%$ & \\
\hline
\end{tabular}

Source: Internal unpublished report on the sale of wine after the fair, Vršački Vinogradi a.d.

Note: * The number of buyers shows the total number of buyers of Vršački vinogradi per category after 3 months. The possibility of double purchase is eliminated, and it may appear only as a consequence of multiple purchases in different months or due to the several purchases of both of the new products in the same months; ** May have and may have not visited the trade fair; $\mathrm{n}$ - number of buyers.

The research shows that the level of consciousness about the product is higher for the visitors of the stand in comparison with those who did not visit the stand. It supports the Presumption P3. The different attitudes about the products which are consequence of the difference between the levels of consciousness of those buyers, who did and did not visit the stand, can be taken as certain ,certainties". When we talk about the level of interest for the products of the company, it is notable that there is a difference between the buyers who did and did not visit the fair when the categories of small and big buyers are concerned. It proves the P4.

The research proves that the potential buyers are totally coexistent with previously established presumptions in both level of consciousness and the level of interest. The bigger number of researches would give better and more relevant data.

The results of the research show that the trade fairs are the efficient instrument of sales improvement and that we can, up to some point, influence the level of interest of the buyers and the decision making on purchase. Certain papers and studies (like Ballesteret al., 2008), give a hint that the wine experts (including winemakers) would perform better in a role of 
assessing the attributes of wine and its quality than the new consumers.

We can therefore conclude that the shown research made a solid ground for the efficient decision making in the process of management when the trade fair appearance is concerned, which in turn could be considered an excellent tool for sales improvement and marketing communication. Domestic companies can, by applying strategic approach to the trade fair appearances, achieve their business objectives in terms of communicational and economic effects. Domestic companies, as proven in this paper, can achieve their business objectives in terms of target groups of buyers and consumers. According to the data enlisted, it is necessary to increase the wine production with the simultaneous change of structure from the point of view of quality, and according to the market demands (Vlahović et al., 2011).

\section{Conclusion}

The results of this research show that the trade fairs can have positive profit rate on investment during trade fair appearance when the companies introduce new products on the market. It is shown that the trade fairs have significant role in later phases of the purchasing process, in creating interest for the new products exhibited at trade fairs, possible creating of consciousness about the mere existence of the product etc. The objective of this research is not a general conclusion, but we can make a partial conclusion that the trade fairs achieve positive profit rate on investments, in terms of consciousness, interest, acquiring new buyers, purchase effects compared to the costs. This situation is the most realistic in case of introducing new product on the market, which have low cost per unit. Trade fairs are accepted as a significant instrument of communication between the company and the market, but their efficiency was contested without the approval made by scientific researches. The results of any empirical or scientific research must be double checked in a large number of cases, different market situations etc. The contribution of this research can therefore be a good start in this direction.

\section{References}

1. Ballester, J., Patris, B., Symoneaux, R., Valentin, D. (2008): Conceptual vs. Perceptual Wine Spaces: Does Expertise Matter?, Food Quality and Preference, vol. 19, no. 3, pp. 267-276.

2. Oczkowski, E., Doucouliagos, H. (2014):Wine prices and quality ratings: a metaregression analysis, American Journal of Agricultural Economics, Milwaukee, USA, available at: http://ajae.oxfordjournals.org/content/early/2014/07/12/ajae.aau057. full.pdf

3. Pennerstorfer, D., Weiss, C. R. (2012): Product quality in the agri-food chain: do cooperatives offer high-quality wine?, European Review of Agricultural Economics, vol. 40, no. 1, pp. 143-162, European Association of Agricultural Economists, Den Haag, the Netherlands, available at: http://erae.oxfordjournals.org/content/40/1/143. abstract?sid=43d33769-ddc2-40d7-8320-408c62597956 
4. Prdić, N. (2009): Sajmovi Građevinarstva - Instrument Marketing Komuniciranja, neobjavljen magistarski rad, Ekonomski Fakultet Subotica, Subotica.

5. Prdić, N. (2012a): Sajmovi kao instrument integrisanog komunikacijskog miksa, neobjavljena doktorska disertacija, Univerzitet EDUCONS, SremskaKamenica.

6. Prdić, N. (2012b): Efekti nastupa preduzeća na sajmu, Anali ekonomskog fakulteta u Subotici, Ekonomski fakultet, Subotica, vol. 28, str. 133-143.

7. Questionnaire for the fair exhibitors and visitors, Prdić, N. - author of the Questionnaire, $79^{\text {th }}$ International agricultural fair, Novi Sad, 12-18 May, 2012.

8. Saenz Navajas, M. P., Tao, Y. S., Dizy, M., Ferreira, V., Fernandez-Zurbano,P. (2010): Relationship Between Non-volatile Composition and Sensory Properties of Premium Spanish Red Wines and their Correlation to Quality Perception, Journal of Agricultural and Food Chemistry, vol. 58, no. 23, pp. 12407-12416.

9. Schamel, G. (2003): A Hedonic Pricing Model for German Wine, German Journal of Agricultural Economics, vol. 52, no. 5, pp. 247 - 254, Institute of Economic and Social Sciences of Agriculture, Berlin, Germany, available at: www.gjae-online.de/ news/pdfstamps/freeoutputs/GJAE-268 2003.pdf

10. Vlahović, B., Tomić, D., Puškarić, A. (2011): Promene na tržištu vina u zemljama CEFTA grupacije, Ekonomika Poljoprivrede, IEP, Beograd, Srbija, vol. 58, no. 4, pp. 609-620.

11.AUMA (Association of the German Trade Fair Industry), available at: www. auma.de/en/TradeFairMarket/KeyFigures/InternationalExhibitions/Seiten/ Development2009-2013.aspx, accessed at October, 2013.

12.Internal unpublished report on the sale of wine after the fair, company Vršački Vinogradi a.d., Vršac, September, 2012. 


\title{
PRAKTIČNI REZULTATI ISTRAŽIVANJA USPEŠNOSTI NASTUPA PREDUZEĆA NA SAJMU
}

\author{
Nedeljko Prdić4, Boris Kuzman ${ }^{5}$, Miljana Barjaktarovic ${ }^{6}$
}

\section{Sažetak}

Sajmovi su aktuelna tema kako u savremenoj teoriji, tako i u praksi uspešnih svetskih a u budućnosti i domaćih preduzeća, organizatora i vlasnika izložbenog prostora. U domaćoj literaturi postoje radovi koji teoretski obrađuju ovu problematiku, međutim nedostaje strateški pristup sajmu kao instrument unapređenja prodaje, kao i istraživanje praktičnog nastupa preduzeća na sajmu i merenje ostvarenih rezultata nastupa.

U radu je dokazano da je nastup na sajmu imao pozitivan efekat na rezultate prodaje kao i na stvaranje interesa i povećanje svesnosti o postojanju preduzeća i njegovih proizvoda. Analizom je utvrđeno da se pod određenim uslovima, može izmeriti i kvantificirati stopa prinosa na investiciju prilikom nastupa na sajmu.

Ključne reči: Sajmovi, vino, troškovi, efekti nastupa.

4 Dr Nedeljko Prdić, JKP Tržnica, ŽikePopovića 4, 21000 Novi Sad, Srbija, Telefon: +381 63500 818, E-mail: ekonomistdoo@sbb.rs

5 Doc. dr Boris Kuzman, Naučni saradnik, Poljoprivredni fakultet, Trg Dositeja Obradovica 8, 21000 Novi Sad, Srbija, Telefon: +381 63590 129, E-mail: kuzmanboris@yahoo.com

6 Prof. dr Miljana Barjaktarović, Alfa Univerzitet, Palmira Toljatija 3, 11000 Beograd, Srbija, Telefon: +381 6944106 20, E-mail: miljana.barjaktarovic@alfa.edu.rs 